\title{
Analisis kemampuan berpikir kritis ditinjau dari keterampilan argumentasi siswa melalui model Argument Based Science Inquiry (ABSI)
}

\author{
Yuliana Ika \\ Prodi Pendidikan Fisika, Universitas Kanjuruhan Malang, Indonesia \\ Surat-e: hesti@unikama.ac.id \\ Hestiningtyas Yuli Pratiwi* \\ Prodi Pendidikan Fisika, Universitas Kanjuruhan Malang, Indonesia \\ Surat-e: hesti@unikama.ac.id
}

\section{Chandra Sundaygara}

Prodi Pendidikan Fisika, Universitas Kanjuruhan Malang, Indonesia

Surat-e: chandrakirana@unikama.ac.id

\begin{abstract}
Abstrak. Berpikir kritis merupakan proses berpikir untuk menganalisis apa yang dimaksud dibalik informasi yang disampaikan. Penelitian ini bertujuan mengetahui kemampuan berpikir kritis dan keterampilan argumentasi siswa melalui model pembelajaran Argument Based Science Inquiry (ABSI) dan pembelajaran berbasis inkuiri, serta mengetahui interaksi antara model pembelajaran ABSI dan keterampilan argumentasi siswa terhadap kemampuan berpikir kritis. Penelitian dilaksanakan di salah satu sekolah negeri di Kota Malang pada semester genap 2019/2020. Populasi penelitian adalah peserta didik kelas X MIPA dan jumlah sampel terdiri dari enam puluh empat peserta didik yang terbagi dalam dua kelompok kelas yakni kelas eksperimen dan kelas kontrol. Teknik pengambilan data menggunakan tes kemampuan berpikir kritis dan mengukur keterampilan argumentasi menggunakan angket. Analisis data menggunakan anova dua jalur. Hasil penelitian menunjukkan bahwa (1) Kemampuan berpikir kritis siswa yang belajar melalui model pembelajaran ABSI lebih tinggi dari pada siswa yang belajar dengan pembelajaran berbasis inkuiri, (2) Kemampuan berpikir kritis siswa yang belajar melalui model pembelajaran ABSI lebih tinggi daripada siswa yang belajar dengan model pembelajaran berbasis inkuiri, (3) Tidak ada interaksi antara model pembelajaran ABSI dan keterampilan argumentasi siswa terhadap kemampuan berpikir kritis.
\end{abstract}

Kata kunci: argument based science inquiry, berpikir kritis, keterampilan argumentasi

\begin{abstract}
Critical thinking is a thought process to analyze what is meant behind the information conveyed. This study aims to determine students 'critical thinking skills and argumentation skills through the Argument Based Science Inquiry (ABSI) learning model and inquiry-based learning, as well as to determine the interaction between the ABSI learning model and students' argumentation skills on critical thinking skills. The research was conducted at one of the public schools in Malang City in the even semester of 2019/2020. The study population was students of class X MIPA and the sample size consisted of sixty-four students who were divided into two class groups, namely the experimental class and the control class. The data collection technique used tests of critical thinking skills and measured argumentation skills using a questionnaire. Data analysis using two-way ANOVA. The results showed that (1) The critical thinking ability of students who learn through the ABSI learning model is higher than students who learn with inquiry-based learning, (2) The critical thinking ability of students who learn through the ABSI learning model is higher than students who learn using the ABSI learning model. Inquiry-based learning, (3) There is no interaction between the ABSI learning model and students' argumentation skills on critical thinking skills.
\end{abstract}

Keywords: argument based science inquiry, critical thinking, argumentation skills 


\section{Pendahuluan}

Pembelajaran fisika merupakan salah satu proses pendidikan mengenai kejadian-kejadian di alam sekitar yang diterapkan menggunakan pendekatan ilmiah sehingga siswa dituntut untuk mampu mempraktikkan dan mengkomunikasikan hasil yang diperoleh selama proses pembelajaran [1]. tujuan pembelaran fisika atau sains tidak hanya penguasaan konsep-konsep ilmiah, tetapi juga belajar tetapi juga belajar bagaimana untuk terlibat dalaam wacana ilmiah [2] [3].

Namun kenyataan proses pembelajaran di kelas menggunakan metode diskusi, ceramah dan tanya jawab, belum menggunakan model pembelajaran yang dapat meningkatkan kemampuan berpikir kritis peserta didik, sehingga hanya sebagian peserta didik yang memfokuskan perhatiannya dalam proses pembelajaran. Rendahnya rasa keingintahuan peserta didik tersebut tersebut berdampak terhadap kemampuan berpikir kritisnya [4]. Permasalahan terbesar dalam pembelajaran saat ini adalah kurannya memberi kesempatan siswa untuk berpartisipasi dalam pembelajaran, pengalaman belajar yang sedikit dan kurangnya usaha pemgembangan keterampilan berargumentasi yang mengarahkan siswa untuk berpikir kritis [5]. Hal ini menyebabkan kemampuan berpikir kritis sains siswa kurang terbentuk. Selain itu, proses pembelajaran yang terjadi belum memaksimalkan siswa baik secara fisik maupun psikisnya untuk dapat menyerap lebih banyak informasi dan belum memperhatikan keterampilan berpikir siswa [6]. Hal ini sedikit tidak sesui dengan tuntutan abad 21, dimana siswa tidak hanya dituntut untuk memahami konsep tetapi juga keterampilan berpikir kritis, keterampilan teknologi informasi dan komunikasi, keterampilan memecahkan masalah, keterampilan berpikir efektif dan keterampilan berkolaborasi [7].

Kemampuan berpikir kirtis siswa diwujudkan melalui cara berkomunikasi dan mengungkapkan materi yang dipahami [8]. Berpikir kritis adalah berpikir dengan menghubungkan, mengevaluasi, mengumpulkan, mengorganis.ir, mengingat dan menganalis informasi semua aspek situasi atau masalah. Indikator berpikir kritis siswa diantaranya adalah: (1) mampu memahami dan merumuskan pokok permasalahan, (2) mampu mengungkapkan alasan berdasarkan fakta/bukti, (3) mampu membuat/memilih argumen yang logis, relevan dan akurat, (4) mampu menjelaskan maksud dari argument yang dibuat berdasarkan sudut pandang yang berbeda dan (5) mampu menentukan akibat dari suatu argumen yang diambil sebagai suantu keputusan.

Argumentasi merupakan salah satu cara yang dapat digunakan untuk memantapkan pemahaman sains siswa. Siswa akan belajar mengambil langkah dalam penyelesain masalah yang disajikan. Argumentasi perlu dimasukkan kedalam komponen inti pembelajaran sain, karena argunmentasi dapat membantu siswa untuk terlibat dalam pembentukan atau konstruksi gagasan ilmiah dan belajar tentang bagaimana cara kerja ilmiah Bricker \& Bell (2008) dalam [9]. Melalui argumentasi yang diungkapkan Guru dapat melihat perkembangan pengetahuan siswa. Selain itu ketika siswa dapat mengungkapkan hasil pemikirannya maka dapat mempengaruhi daya pikir kritis sisiwa. Artinya, berpikir kritis juga dapat dipengaruhi oleh keterampilan argumentasi siswa. Berdasarkan Toulmin's Argumentation Pattern (TAP) komponen argumentasi terdiri atas klaim (claim), data (Data), pembenaran (warrant), dukungan (backing) dan sanggahan (rebuttal). Klaim adalah hasil dari nilai-nilai yang ditetapkan pendapat mengenai nilai situasi yang ada atau penegasan dari sudut pandang. Data merupakan fenomena yang digunakan sebagai bukti untuk mendukungkalim. Pembenaran adalah aturan dan prinsip-prinsip yang menjelaskan hubungan antara data dan klaim. Dukungan adalah dasar asumsi yang melandasi pembenaran tertentu. Sanggahan adalah kasus-kasus tertentu saat klaim tidak dapat dibuktikan (verified) atau adanya argumen-argumen yang berbeda [10].

Salah satu materi fisika yang penting dipahami oleh siswa adalah materi Hukum Newton. Materi Hukum Newton dianggap memiliki objek nyata yang sering ditemui oleh peserta didik dalam kehidupan sehari-hari sehingga hal ini akan mempermudah peserta didik dalam memahami fenomena yang ditampilkan dan mempermudah peserta didik dalam merancang kegiatan ilmiah [11].

Salah satu model pembelajaran yang membantu siswa untuk mengembagkan kemampuan berpikir kritisnya sehingga siswa menjadi aktif dan pembelajaran menjadi berpusat pada siswa adalah model pembelajaran Argument Based Science Inquiry (ABSI). Berdasarkan penelitian yang telah dilakukan mengenai pemerapan model ABSI, dinyatakan bahwa model pembelajaran ABSI berperan penting dalam memberikan peluang kepada siswa untuk menyampaikan argumentasinya baik dalam diskusi kelompok maupun kelas [8]. Hasil penelitian Subarkah [12] menjelaskan bahwa penerapan model pembelajaran (ABSI) dapat meningkatkan kemampuan ilmiah dan berargumentasi siswa. Model pembelajaran ABSI mampu meningkatkan kemampuan kognitif siswa, berargumentasi, menulis dan kemampuan berpikir kritis siswa [13]. Pembelajaran Argument Based Science Inquiry (ABSI) memberikan kesempatan kepada siswa untuk 
melakukan kegiatan praktikum secara inkuiri, memberikan kesempatan untuk melakukan diskusi kelompok kecil dan diskusi kelas sehingga siswa dilatih untuk berargumentasi yang mana argumenatsinya tersebut didasarkan atas hasil kegiatan inkuiri sains. Dengan kata lain pembelajaran ABSI dapat memfasilitasi kegiatan penyelidikan dan membangun berarumentasi siswa [14]. Adapun tahap-tahap model pembelajaran ABSI adalah : (1) eksplorasi pemahaman sebelum pembelajaran, (2) partisipasi dalam kegiatan praktikum, (3) menulis pengertian individu untuk kegiatan praktikum, (4) bertukar pikiran dan membandingkan interpretasi data dalam kelompok kecil, (5) membandingkan ide-ide sains dengan buku teks atau sumber lainnya, melalui diskusi kelas (6) refleksi dan menulis secara individu, (7) ekplorasi pemahaman setelah pembelajaran, yaitu penguatan materi dan membuat kesimpulan. Jadi dapat dikatakan bahwa dalam pembelajaran ABSI siswa dilatih untuk berargumentasi.

Kemampuan berpikir kirtis siswa diwujudkan melalui cara berkomunikasi dan mengungkapkan materi yang dipahami [8]. Berpikir kritis adalah berpikir dengan menghubungkan, mengevaluasi, mengumpulkan, mengorganisir, mengingat dan menganalis informasi semua aspek situasi atau masalah. Adapun beberapa indikator yang membantu penenliti dalam menentukan kemampuan berpikir kritis siswa diantaranya adalah: (1) mampu memahami dan merumuskan pokok permasalahan, (2) mampu mengungkapkan alasan berdasarkan fakta/bukti, (3) mampu membuat/memilih argumen yang logis, relevan dan akurat, (4) mampu menjelaskan maksud dari argument yang dibuat berdasarkan sudut pandang yang berbeda dan (5) mampu menentukan akibat dari suatu argumen yang diambil sebagai suantu keputusan.

Dengan adanya model pembelajaran ABSI mampu membantu siswa menghadapi tuntutan abad 21 sebagai kemampuan berpikir kritis dan kreatif. Dimana berpikir dapat diwujudkan melalui cara berkomunikasi dan mengungkapkan materi yang dipahami. Diharapkan hasil akhir penelitian dapat menjadi landasan dalam meningkatkan kemampuan berpikir kritis dan keterampilan argumentasi.

\section{Metode Penelitian}

Penelitian ini merupakan penelitian kuantitatif. Desain penelitian adalah eksperimen semu (Quasi experiment design) dengan rancangan penelitian menggunakan posttest only control group design. Populasi dalam penelitian ini yaitu seluruh siswa kelas X MIPA 3 dan X MIPA 4 di salah satu SMA Negeri di Kota Malang yang masih tercatat aktif sebagai siswa di sekolah, yaitu terdiri dri dua kelas dengan julah keseluruhan 64 siswa

Sampel dalam penelitian ini berjumlah 64 siswa, dimana siswa tersebut dibagi atas dua kelas yaitu kelas X MIPA 3 sebagai kelas kontrol yang mendapat pembelajaran berbasis inkuiri, dengan jumlah 32 siswa dan kelas X MIPA 4 sebagai kelas eksperimen yang mendapat pembelajaran model Argument Based Science Inquiry (ABSI) dengan jumlah 32 siswa. Dalam penentuan kelas kontrol dan kelas eksperimen ditentukan berdasarkan pertimbangan dari peneliti karena kedua kelas tersebut mempunyai kemampuan yang sama sehingga memiliki hak yang sama juga untuk dijadikan kelas kontrol maupun eksperimen.

Adapun variabel dalam penenlitian, yaitu: Variabel Indenpendent atau variabel bebas merupakan variabel yang mempengaruhi variabel terikat. Dalam penelitian ini variabel bebasnya adalah model pembelajaran argument based science inquiry (ABSI). Variabel Dependent atau variabel terikat adalah variabel yang yang dipengaruhi oleh variabel bebas atau yang menjadi akibat karena adanya variabel bebas. Dalam penelitian ini adalah kemampuan berpikir kritis siswa. Variabel Moderat, variabel moderat dalam penenlitian ini adalah keterampilan argumentasi siswa.

Metode yang digunakan dalam pengambilan data dalam penelitian ini adalah metode dokumentasi tes. Metode dokumentasi digunakan untuk memdapatkan data nilai fisika siswa pada materi sebelumnya. Data tersebut digunakan untuk penyesuaian antara kelas kontrol dan eksperimen. Metode tes digunakan untuk mendapatkan data kemampuan berpikir kritis dan keterampilan argumentasi siswa dengan instrumen yang sudah layak digunakan. Tes diberikan pada kedua kelas untuk mendapatkan data nilai akhir dengan bentuk tes yang digunakan yaitu tes uraian atau subjektif untuk berpikir kritis dan lembar observasi (angket) digunakan untuk mendapatkan data keterampilan argumentasi siswa. Lembar observasi (angket) akan diisi oleh peneliti yang berisi indikator-indikator seorang siswa yang dikategorikan memiliki keterampilan argumentasi. Setelah dilakukan uji coba instrumen motode tes dan menganalisis hasilnya untuk mengatahui validitas, reliabilitas, daya pembeda, taraf kesukaran dan mengambil soal yang layak digunakan dalam tes kemampuan bepikir kritis 
dan lembar observasi (angket) dilakukan uji validitas dan reliabilitas untuk mengetahui kevalidan angket sebelum tes keterampilan argumentasi siswa.

Data awal yang digunakan yaitu data nilai materi sebelumnya yang diperoleh siswa dari kedua kelas. Data tersebut diuji dengan uji normalitas dan homogen agar layak diberikan perlakuan. Data akhir hasil penelitian diperoleh dari nilai tes kemampuan berpikir kritis dan keterampilan argumentasi siswa setelah kelas kontrol dan kelas eksperimen diberi perlakuan dimana pada kelas kontrol dengan pembelajaran berbasis inkuiri dan eksperimen dengan model ABSI. Selajutnya data hasil tersebut dianalisis dengan uji normalitas, uji homogenitas, uji hipotesis yakni anova dua jalur.

\section{Hasil Penelitian dan Pembahasan}

Perolehan data dari penelitian ini yaitu data kuantitatif yaitu data kemampuan berpikir kritis dan keterampilan argumentasi siswa yang selanjutnya diolah menggunakan SPSS 16.0 for windows. Sebelum instrument test posttest dan angket keterampilan argumentasi digunakan pada tahap pelaksanaan penelitian, terlebih dahulu instrument diuji untuk mengetahui layak dan tidaknya digunakan. Instrument kemampuan berpikir kritis yang digunakan berjumlah 10 soal dan angket keterampilan argumentasi dengan 3 item yang diujikan kepada 32 reponden. Sepuluh butir soal dan tiga item angket tersebut.

Hasil analisis secara statistik menunjukkan bahwa kemampuan berpikir kritis siswa yang belajar dengan ABSI lebih tinggi dibandingkan dengan kemampuan berpikir kritis siswa yang belajar menggunakan pembelajaran berbasis inkuiri.

Tabel 1. Hasil Analisis Uji Anova

\begin{tabular}{cc}
\hline Sumber & Sig \\
\hline \hline Model Pembelajaran & 0,014 \\
\hline $\begin{array}{c}\text { Model ABSI vs pembelajaran berbasis } \\
\text { inkuiri }\end{array}$ & 0,000 \\
$\begin{array}{c}\text { Model Pembelajaran*Keterampilan } \\
\text { argumentasi }\end{array}$ & 0,000 \\
\hline
\end{tabular}

Hal ini dibuktikan dengan hasil analisis menggunakan anova dua jalur yaitu $\operatorname{Sig}<\alpha(0,014<0,05)$. Hal ini disebabkan karena penerapan model pembelajaran ABSI melibatkan siswa dalam menemukan solusi memalui praktikum yang berbasis inkuiri secara kelompok, beradu argument dalam kelompok sesuai data hasil praktikum dan melakukan diskusi kelas membandingkan ide-ide tersebut dengan buku atau sumber lainnya. Dengan adanya keterlibatan dalam proses argumentasi ilmiah tersebut mendukung penguatan keterampilan berpikir kritis peserta didik. Hasil penelitian ini sejalan dengan penelitian yang dilakukan oleh A. Budiyono [14] yang menunjukkan bahwa model pembelajaran ABSI membeikan dampak dalam meningkatkan keterampilan argumentasi yang nantinaya akan merujuk pada peningkatan kemampuan berpikir kritis siswa. Keterampilan argumentasi memberikan dampak yang baik terhadap kemampuan berpikir kritis siswa [15]. Indikator berpikir kritis secara detail dapat dilihat pada tabel berikut.

Tabel 2. Indikator Berpikir Kritis Siswa

\begin{tabular}{|c|l|l|l|}
\hline No & \multicolumn{1}{|c|}{ Indikator } & \multicolumn{1}{c|}{ Aspek } & \multicolumn{1}{c|}{ Contoh soal } \\
\hline \hline 1 & $\begin{array}{l}\text { Mampu merumuskan } \\
\text { pokok permasalahan }\end{array}$ & $\begin{array}{l}\text { - Mencari pernyataan } \\
\text { yang jelas dari setiap } \\
\text { pertanyaan }\end{array}$ & $\begin{array}{l}\text { Burnay dan Rose sedang membuka-buka buku } \\
\text { catatan Fisika tantang Hukum-hukm Fisika } \\
\text { yang sudah lama tidak dibuka. Mereka } \\
\text { membaca buku tersebut dengan saksama. Lalu } \\
\text { Rose dan Burnay menemukan kalimat tersebut: } \\
\text { "Benda yang diam sama dengan benda yang } \\
\text { bergerak dengan percepatan nol". Dalam buku } \\
\text { tersebut tidak terdapat penjelasan lanjutan } \\
\text { mengenai kalimat diatas. Kalimat tersebut }\end{array}$ \\
\hline
\end{tabular}


Argument Based Science Inquiry (ABSI)

\begin{tabular}{|c|c|c|c|}
\hline No & Indikator & Aspek & Contoh soal \\
\hline & & & $\begin{array}{l}\text { menunjukkan Hukum apa? Benarkah } \\
\text { pernyataan tersebut? Alasan! }\end{array}$ \\
\hline 2 & $\begin{array}{l}\text { Mampu mengungkapkan } \\
\text { fakta yang dibutuhkan } \\
\text { dalam menyelesaikan suatu } \\
\text { masalah }\end{array}$ & $\begin{array}{l}\text { - Berusaha mengetahui } \\
\text { informasi dengan baik } \\
\text { - Mengunakan sumber } \\
\text { yang memiliki } \\
\text { kredibilitas dan } \\
\text { menyebutkannya } \\
\text { - Mengingat } \\
\text { kepentingan asli dan } \\
\text { mendasar }\end{array}$ & $\begin{array}{l}\text { Suanta sedang medorong meja yang bermassa } \\
m \text {, Suanta memberikan gaya } F \text { yang } \\
\text { menimbulkan percepatan } a \text { pada meja } \\
\text { tersebut. Jika gaya yang diberikan Suanta } \\
\text { diperbesar 2x semula dan massa meja menjadi } \\
\text { 4x massa semula, maka percepatan yang } \\
\text { ditimbulkan meja menjadi . . ...... Alasan: }\end{array}$ \\
\hline 3 & $\begin{array}{l}\text { Mampu memilih argumen } \\
\text { logis, relevan dan akurat }\end{array}$ & $\begin{array}{l}\text { - } \text { Mencari alasan } \\
\text { - Berusaha tetap } \\
\text { relevan dengan ide } \\
\text { utama } \\
\text { - Sistematis dan teratur } \\
\text { dari keseluruhan } \\
\text { masalah }\end{array}$ & $\begin{array}{l}\text { Pernyataan : Jika resultan yang bekerja pada } \\
\text { benda sama dengan nol, maka benda tersebut } \\
\text { akan bergerak dengan kecepatan berubah- } \\
\text { ubah! } \\
\text { Alasan : Jika resultan yang bekerja pada } \\
\text { benda sama dengan nol, maka benda tersebut } \\
\text { akan tetap dalam keadaan diam! } \\
\text { Jawaban yang benar adalah ..... apakah } \\
\text { pernyataan benar/salah dan apakah alasan } \\
\text { benar/salah. Jika salah, berikan alasanmu } \\
\text { bagaimana benarnya! }\end{array}$ \\
\hline 4 & $\begin{array}{l}\text { Mampu menjelaskan } \\
\text { maksud arguemn } \\
\text { berdasarkan sudut pandang } \\
\text { yang berbeda }\end{array}$ & $\begin{array}{l}\text { - Mencari alternatif } \\
\text { - Mengambil posisi } \\
\text { ketika ada bukti yang } \\
\text { cukup untuk } \\
\text { melakukan sesuatu } \\
\text { - Mencari penjelasan } \\
\text { sebanyak mungkin } \\
\text { apabila } \\
\text { memungkinkan }\end{array}$ & $\begin{array}{l}\text { Maylan sedang menangis diujung jalan } \\
\text { meminta ibunya untuk menaiki becak saat } \\
\text { pulang dari pasar karena Ia ingin mencoba } \\
\text { merasakan naik diatas becak. Ibunya pun } \\
\text { memanggil tukang becak yang duduknya } \\
\text { lumayan jauh dari tempat mereka berdiri. } \\
\text { Maylan dan Ibunya melihat dari jauh tukang } \\
\text { becak berjalan kearahnya dengan kecepatan } \\
\text { konstan } v_{1} \text { kemudian tukang becak tersebut } \\
\text { mempercepat kecepatan becaknya sehingga } \\
\text { kecepatannya menjadi } v_{2} \text { dan lebih cepat lagi } \\
\text { menjadi } v_{3} \text {. Jika kecepatan becak tersebut } \\
\text { beraturan, maka besar resultan gaya pada saat } \\
\text { kecepatan becak } v_{1}, v_{2} \text {, dan } v_{3} \text { adalah. . . } \\
\text { Alasan: }\end{array}$ \\
\hline 5 & $\begin{array}{l}\text { Mampu menentukan akibat } \\
\text { dari suatu argumen yang } \\
\text { diambil sebagai suatu } \\
\text { keputusan }\end{array}$ & $\begin{array}{l}\text { - Memperhatikan } \\
\text { situasi dan kondisi } \\
\text { secara keseluruhan } \\
\text { - Bersikap dan berpikir } \\
\text { terbuka }\end{array}$ & $\begin{array}{l}\text { Rika dan Bima sedang membaca buku untuk } \\
\text { mempersiapkan ulangan Fisika esoknya. } \\
\text { Beberapa menit kemudian Bima merasa pusing } \\
\text { dengan rumus Fisika dan mengantuk, hingga } \\
\text { pada akhirnya Bima berdiri dan meletakkan } \\
\text { buku Fisika yang iya pelajari di atas meja } \\
\text { belajar. Menurut Rika pernyataan yang benar } \\
\text { untuk menggambarkan keadaan buku yang } \\
\text { diletakkan Bima tersebut adalah ........ Alasan! }\end{array}$ \\
\hline
\end{tabular}

Penerapan model pembelajaran Argumen Based Science Inquiry (ABSI dilakukan pada kelas eksperimen. Penggunaan model ini dimulai dengan tahap pertama yaitu tahap eksplorasi pemahaman sebelum pembelajaran merupakan tahap untuk siswa melakukan senam otak dimana siswa diberikan tayangan vidio berupa peristiwa representasi visual dan menyiapkan pertanyaan yang mengarahkan pemikiran siswa tentang permasalahan yang akan dijumpai, diselidiki dan dipecahkan dalam proses pembelajaran. Tahap ini bertujuan untuk menumbuhkan rasa ingin tahu siswa terhadap materi pembelajaran dan meransang kemampuan berpikir kritis siswa sehingga siswa mampu merumuskan pokok permasalahan yang akan diselesaikan sesuai dengan indikator berpikir kritis yang pertama. Selanjutnya membuktikan, indikator ini dilaksanakan atau diberikan pada tahap partisipasi dalam praktikum. Pada kegiatan ini siswa telebih dahulu dibagi menjadi beberapa 
kelompok, kemudian siswa menyusun metode dan mengumpulkan data. Pada tahap pengumpulan data ini siswa melakukan penyelidikan atau praktikum untuk mencari dan membuktikan mengenai permasalahan yang diberikan dengan data hasil praktikum. Kemudian data tersebut diolah dengan menghubungkan dengan berbagai sumber informasi lain termasuk mengkaitkannya dengan informasi yang siswa sebelumnya punya lalu menyampaikannya pada tahap interaktif argumen. Hal ini berkesuaian dengan yang dikatakan oleh Syifa'ul [16] mengenai teori pemrosesaan informasi merupakan teori belajar kognitif yang berkaitan dengan cara seseorang memperoleh dan memproses informasi, menyimpan informasi, dan pemanggilan kembali pengetahuan dari pikiran.

Indikator membuat argumen, dilaksanakan tahap menulis argumen individu sementara atau klaim dan bertukar pikiran dalam kelompok kecil. Pada tahap ini guru mengarahkan siswa untuk menginterprestasikan data praktikum dan mengarahkan siswa membuat pernyataan sementara atau klaim. Kemudian siswa melakukan diskusi dalam kelompok terkait penguatan pernyataan sebelumnya sesuai dengan data hassil percobaan dan disertai bukti pernyataannya. Seseorang mempunyai kemampuan argumentasi melalui pencapaiannya dalam memahami fenomena yang dialaminya, mengemukakan pemahamannya dan meyakinkan orang lain agar menerima gagasannya Berland dan Hammer (2012). Sehingga, dalam kedua tahap ini siswa dapat meningkatkan kemampuan berpikir kritisnya melalui penyelidikan dan berargumen yang disampaikan dalam diskusi. Selanjutnya menjelaskan maksud dari suatu argumen, indikator ini dapat dilihat pada membandingkan argumentasi dengan buku atau sumber lain, dalam tahap ini siswa membandingkan atau menghubungkan hasil percobaan dalam bentuk klaim atau pernyataan dengan berbagai sumber informasi lain termasuk mengkaitkannya dengan informasi yang siswa sebelumnya dimiliki. Lalu menyampaikannya pada tahap interaktif argumen dalam bentuk diskusi kelas, sehingga siswa mampu mengambil kesimpulan atau keputusan berdasarkan sudut pandang yang berbeda. Dalam kedua tahap ini siswa dapat menghasilkan argumen yang berisi klaim, bukti, dan dukungan kemudian menilai dan merevisi argumen. Argumentasi dapat menjadi sangat penting untuk meningkatkan keterampilan berpikir kritis. Selanjutnya mengambil keputusan dan mengevaluasi kesesuaian pemahaman, indikator ini dapat dilaksanakan pada tahap menulis secara individu dan menyimpulkan. Pada tahap ini siswa membuat laporan dari percobaan yang sudah dilakukan dalam bentuk argumen akhir dari hasil diskusi kelas secara individu dan terlibat aktif dengan bersikap dan berpikir terbuka dalam menyimpulkan jawaban yang telah diuji dengan argumen sebelumnya, sehingga dapat diperoleh argumen yang benar atau salah. Sehingga siswa mampu menyimpulkan apakah pernyataannya berubah setelah melakukan percobaan.

Indikator-indikator ini memiliki peranan penting dalam menentukan kemampuan berpikir kritis siswa. Dimana dengan adanya indikator-indikator peneliti memiliki dasar atau acuan sehingga siswa dikatakan mampu berpikir kritis. Dengan langkah-langkah yang dimiliki pembelajaran ABSI dikatakan bahwa proses belajar untuk mencari menerima, dan mengolah data atau informasi untuk dijadikan sebuah pengetahuan yang didapatkan melalui proses pembelajaran sehingga indikator-indikator berpikir kritis dapat ditemukan dalam setiap langkah-langkah tersebut yang mengakibatkan kemampuan berpikir kritis siswa lebih tinggi dibandingkan dengan menggunakan pembelajaran berbasis inkuiri.

Kemampuan berpikir kritis siswa dengan keterampilan argummentasi tinggi dan rendah yang belajar menggunakan Argument Based Science Inquiry (ABSI) lebih tinggi dibandingakn dengan keterampilan argumentasi tinggi yang belajar menggunakan pembelajaran berbasis inkuiri. Hal ini dibuktikan dengan hasil analisis menggunakan anova dua jalur yaitu Sig $<\alpha \quad(0,000<0,05)$. Hali ini sesuai dengan penelitian yang dilakukan Khusnayain [17] yang menyatakan bahwa pembelajaran berbasis inkuiri argumentatif merupakan pembelajaran yang sesuai dan mampu memberikan pengalaman belajar kepada siswa dalam meningkatkan keterampilan argumentasi illmiahnya karena siswa akan dituntut untuk membangun penjelasan merekan sendiri dan menuangkan ide-ide yang mereka miliki. Keterampilan argumentasi memiliki indikator-indikator yang menjadikan landasan seseorang memiliki kemampuan argumentasi. Demikian juga dalam penelitian ini indikator keterampilan argumentasi yang digunakan secara detail dijelaskan dalam tabel 3 berikut.

Tabel 5. Indikator kemampuan argumentasi

\begin{tabular}{|c|c|c|}
\hline No & Aspek & Indikator \\
\hline 1 & Klaim & 1) Membuat klaim yang akurat dan lengkap \\
\hline 2 & Data & $\begin{array}{l}\text { 1) Menyediakan bukti yang sesuai dan cukup untuk } \\
\text { mendukung klaim }\end{array}$ \\
\hline
\end{tabular}


2) Kualitas data untuk mendukung klaim

Klaim merupakan jawaban atau pernyataan yang menjawab pertanyaan atau permasalahan. Dalam lembar observasi (angket) indikator keterampilan argumentasi ini diamati pada tahap awal yaitu eksplorasi pemahaman sebelum pembelajaran. Dalam tahap ini siswa diberikan permasalahan yang berupa vidio terkait penerapan materi pembelajaran yang akan dipelajari dan pertanyaan dan siswa menulis pernyataan mereka yang berbentuk klaim. Indikator ini juga dapat dilihat pada point siswa membuat argument sementara, berdiskusi kelompok dan diskusi kelas. Dimanana dalam tahap ini siswa membuat argument sementara, menyampaikan argument mereka dalam berdiskusi dengan teman kelompok dan kelas berdasarkan atau sesuiai dengan data hasil percobaan yang dilakukan. Selanjutnya data, data merupakan informasi yang mendukung suatu pernyataan. Indikator ini dapat dilihat dalam tahap partisipasi dalam praktikum, dalam tahap ini siswa mencari dan menemukan penyelesaian dari permasalahan yang diberikan yang mendukung klaim atau pernyataan. Data adalah salah satu dasar dari suatu argument yang merupakan komponen dikumpulkan sebagai bagian dari investigasi melalui pengukuran atau pengamatan [18].

Kemampuan berpikir kritis siswa yang belajar menggunakan ABSI dan siswa yang belajar menggunakan pembelajaran berbasis inkuiri memilki rentang rata-rata yang tidak signifikan. Rentang rata-rata yang tidak signifikan ini dapat disebabkan oleh cara pengelompokkan siswa yang digunakan dalam pembelajarn yang sudah dilakukan tidak secara heterogen. Artinya setiap kelompok siswa yang dibentuk dalam kegiatan belajar tidak terdiri dari siswa yang berkemampuan akademik tinggi sedang maupun rendah. Corebima [19] mengemukakan bahwa guru hendaknya memperhatikan pembelajaran yang berpotensi besar meningkatkan hasil belajar siswa terutama yang lebih menguntungkan para siswa berkemampuan akademik bawah. Siswa yang berkemampuan rendah tidak akan mampu berpartisipasi secara maksimal jika mereka berada dalam kelampok yang juga berkemampuan rendah. Kemampuan berkomunikasi atau berargumen siswa belum berkembang secara maksimal dikarenakan siswa masih malu atau tidak memiliki keberanian untuk mengeluarkan pendapatnya [20]. Siswa yang belum memiliki keberanian berargumentasi membutuhkan waktu yang cukup untuk membiasakan diri dalam menyampaikan pendapat atau berargumen.

Tidak ada interaksi antara pembelajara Argunent Based Science Inquiry (ABSI) dan keterampilan argumentasi terhadap kemampuan berpikir kritis siswa. Hal ini dibuktikan dengan hasil analisis yaitu $\mathrm{Sig}>\alpha$ $(0,937>0,05)$. Hal ini disebabkan oleh beberapa faktor diantaranya siswa yang memilki kemampuan berpikir kritis tinggi tetapi tidak mampu atau kurang memiliki kepercayaan diri untuk berargumentasi. Noviantika (2016) dalam [21] mengatakan bahwa kerpercayaan diri memiliki pengaruh terhadap kemampuan berpikir kritis peserta didik. Penerapan model pembelajaran yang kurang terorganisir sehingga belum membantu menumbuhkan kreativitas siswa dalam memenuhi indikator-indikator dalam keterampilan argumentasi. Terutama dalam pelaksanaan kerja secara kelompok, siswa belum terbagi secara heterogen antara peserta didik yang memiliki kerampilan argumentasi tinggi ataupun memiliki keterampilan argumentasi rendah. Misalnya bagaimana memberikan instruksi di kelas, apresiasi terhadap siswa dan pengelompokkan siswa di kelas. Hal tersebut membuat beberapa siswa mendominasi kelompok secara tidak merata sehingga hanya kelompok tertentu yang memiliki nilai lebih baik dari kelompok lainnya. Guru mempunyai pengaruh besar terhadap proses belajar siswa baik secara lansung maupun tidak langsung,

Pada proses pembelajaran menggunakan model pembelajaran Argument Based Science Inquiry (ABSI), masih memiliki kekurangan peneliti diantaranya yaitu dalam kegiatan membuat argumen dan melakukan diskusi kurannya membentuk memotivasi, mengorganisir siswa dalam mengungkapkan pendapat mereka dengan percaya diri, sehingga siswa yang berperan aktif hanya siswa yang mampu berargumen saja serta pada pembagian kelompok kerja siswa dilakukan tidak secara heterogen antara kemampuan tinggi maupun rendah dan hal ini juga disebabkan karena banyaknya keterbatasan peneliti dalam penelitian yang dilakukan sehingga kurang dapat mengontrol faktor-faktor yang ada diluar kegiatan pembelajaran.

\section{Kesimpulan}

Berdasarkan penelitian dan analisis yang telah dilakukan, dapat disimpulkan bahwa, kemampuan berpikir kritis siswa yang belajar melalui model pembelajaran ABSI lebih tinggi daripada siswa yang belajar dengan model pembelajaran berbasis inkuiri, keterampilan argumentasi siswa yang belajar melalui model 
pembelajaran ABSI lebih tinggi dari pada siswa yang belajar dengan model pembelajaran berbasis inkuiri, dan belum ditemukan/tidak ada interaksi antara model pembelajaran ABSI dan keterampilan argumentasi siswa terhadap kemampuan berpikir kritis siswa.

\section{Kepustakaan}

[1] N. Hayatun, R. Undang, H. Kartini, and H. Neni, "Pengaruh penerapan model argument driven inquiry terhadap ketrampilan berfikir kritis siswa SMP berdasarkan perbezaan kemampuan akademik," J. Pendidik. Fis., vol. 7 , no. 2, pp. 110-117, 2018.

[2] A. Budiyono, D. Rusdiana, and S. I. Kholida, "Pembelajaran Argument Based Science Inquiry ( ABSI ) Pada Fisika,” vol. 2015, no. Snips, pp. 205-208, 2015.

[3] H. Y. Pratiwi, M. N. Hudha, M. Asri, and N. J. Ahmad, "The Impact of Guided Inquiry Model Integrated with Peer Instruction towards Science Process Skill and Physics Learning Achievement," Momentum Phys. Educ. J., vol. 3, no. 2, pp. 78-85, 2019, doi: 10.21067/mpej.v3i2.2768.

[4] E. Saputri, W. Syafi, and F. Elya, "The Implementation of Guided Inquiry Learning Model to Increase Critical Thinking Ability on Biology Learning at Class X SMAN 9 Pekanbaru," Jom Fkip, vol. 5, pp. 1-10, 2018.

[5] W. Wartono, M. N. Hudha, and J. R. Batlolona, "How are the physics critical thinking skills of the students taught by using inquiry-discovery through empirical and theorethical overview?," Eurasia J. Math. Sci. Technol. Educ., vol. 14, no. 2, pp. 691-697, 2018, doi: 10.12973/ejmste/80632.

[6] T. Ompusunggu, B. M. Turnip, and M. Sirait, "Efek Inquiry Training dan Berpikir Kritis Terhadap Keterampilan Proses Sains Fisika," J. Pendidik. Fis., vol. 5, no. 2, 2016.

[7] Chaeruman, E-Learning dalam Pendidikan Fisika Jarak Jauh. Jakarta: Kemendiknas, 2010.

[8] V. Angeline, R. P. Situmorang, and S. Sastrodihardjo, "Korelasi Keterampilan Argumentasi dan Hasil Belajar Siska SMA Kristen Satya Wacana pada Materi Genetika dengan Model ABSI," JIPVA (Jurnal Pendidik. IPA Veteran), vol. 2, no. 1, p. 1, 2018, doi: 10.31331/jipva.v2i1.539.

[9] D. J. Putra, N. Hasnunidah, and T. Jalmo, "Pengaruh Argument Driven Inquiry Terhadap Keterampilan Argumentasi Siswa pada Materi Sistem Pernapasan,” J. Bioterdidik, vol. 7, no. 1, pp. 1-10, 2019.

[10] W. S. Ginanjar, S. Utari, and U. P. Indonesia, "Penerapan Model argument-driven inquiry dalam pembelajaran IPA untuk meningkatkan kemampuan argumentasi ilmiah siswa SMP," no. 1, pp. 1-6.

[11] Hanifah Nur; Admoko Setiyo, "Inovasi Pendidikan Fisika ISSN : 2302-4496 ISSN : 2302-4496 Inovasi Pendidikan Fisika ISSN : 2302-4496 ISSN : 2302-4496,” vol. 08, no. 02, pp. 593-597, 2019.

[12] C. Z. Subarkah, A. Fadilah, and R. Aisyah, "Argument Based Science Inquiry (ABSI) Learning Model in Voltaic Cell Concept,” J. Phys. Conf. Ser., vol. 895, no. 1, pp. 0-6, 2017, doi: 10.1088/17426596/895/1/012008.

[13] M. Demirbag, "Integrating Argument-Based Science Inquiry with Modal Representations : Impact on Science Achievement, Argumentation, and Writing Skills *," vol. 14, no. 1, pp. 386-391, 2014, doi: 10.12738/estp.2014.1.1632.

[14] A. Budiyono, "Pengaruh Penerapan Model Pembelajaran Argument Based Science Inquiry (ABSI) Terhadap Peningkatan Kemampuan Berargumentasi Siswa SMA,” Wacana Didakt., 2016, doi: 10.31102/wacanadidaktika.4.1.84-93.

[15] I. Kaniawati and A. Suhandi, "Penerapan Model Pembelajaran Pembangkit Argumen Menggunakan Metode Saintifik Untuk Meningkatkan Kemampuan Kognitif Dan Keterampilan Berargumentasi Siswa,” J. Pendidik. Fis. Indones., vol. 10, no. 2, pp. 104-116, 2014, doi: 10.15294/jpfi.v10i2.3347.

[16] S. Amamah, C. Sa'dijah, and Sudirman, "Proses Berpikir Siswa SMP Bergaya Kognitif Field Dependen dalam Menyelesaikan Masalah Berdasarkan Teori Pemrosesan Informasi,” J. Pendidik. Teor. Penelitian, dan Pengemb., vol. 1, no. 2, pp. 237-245, 2016.

[17] A. Khusnayani, "Pengembangan Lembar Kerja Siswa Berbasis Argument Driven Inquiry (ADI) untuk Menumbuhkan Keterampilan Argumentasi Ilmiah,” 2017.

[18] N. Faiqoh, N. Khasanah, L. P. Astuti, R. Prayitno, and B. A. Prayitno, "Jurnal Pendidikan Biologi," J. Pendidik. Biol., vol. 8, no. 1, pp. 1-5, 2018.

[19] A. D. Corebima, "Pembelajaran biologi di Indonesia bukan untuk hidup," Semin. Nas. XIII Biol. Sains, Lingkungan, dan Pembelajarannya di Pendidik. Biol. FKIP UNS, vol. 13, no. 1, pp. 8-22, 2016.

[20] I. Tabares et al., "Pengaruh ESAR (Engage, Study, Activate, Reflect) Terhadap kemampuan analisis dan argumentasi ilmiah," J. Teknol., vol. 1, no. 1, pp. 69-73, 2013, doi: 10.11113/jt.v56.60.

[21] S. M. Agnah, Rusdi, and H. Yanti, "Pengaruh Metode Peta Argumen dan Efikasi Diri terhadap Kemampuan Berpikir Kritis,” EduSains, vol. 10, no. 2, pp. 217-225, 2018. 